\title{
Effects of supplementation plan on intake, digestibility, eating behavior, growth performance, and carcass characteristics of grazing beef cattle
}

\section{Efeitos do plano de suplementação sobre o consumo, digestibilidade, comportamento ingestivo, crescimento e características de carcaça de bovinos de corte em pastejo}

\author{
Nelcino Francisco De Paula ${ }^{1 *}$; Mário Fonseca Paulino²; Victor Rezende \\ Moreira Couto $^{3}$; Edenio Detmann²; Ivan França Smith Maciel ${ }^{4}$; Lívia Vieira \\ Barros $^{1}$; Sidnei Antônio Lopes ${ }^{5}$; Ériton Egídio Lisboa Valente ${ }^{6}$; \\ Joanis Tilemahos Zervoudakis ${ }^{7}$; Leandro Soares Martins ${ }^{8}$
}

\begin{abstract}
This study was designed to evaluate the effects of different supplementation plans on the nutrient intake, apparent total-tract digestibility, grazing behavior, growth performance, and carcass characteristics of beef cattle under grazing conditions from ages 4 to 18 months old. The beef calves grazed Brachiaria decumbens in four seasons: rainy-dry transition, dry, dry-rainy transition, and rainy. Forty-four animals (11 per treatment) were randomly assigned to one of four nutritional plans of supplementation defined by the quantity of supplement offered: control, low, medium, and high supplementation. There was no difference $(\mathrm{P}>0.10)$ in dry matter intake $(\mathrm{DMI})$. However, animals receiving medium and high supplementation had decreased $(\mathrm{P}<0.10)$ forage dry matter intake $(\mathrm{FDMI})$ compared with those under non- and low supplementation. The DMI and FDMI were lower $(\mathrm{P}<0.10)$ in the dry season. During the rainy season, the grazing time decreased $(\mathrm{P}<0.10)$ for animals receiving supplementation compared with non-supplemented ones, but was similar between medium and high supplementation. The performance and carcass characteristics were greater $(\mathrm{P}<0.10)$ for high and medium supplementation compared with low and control. In conclusion, increasing the supplementation plans for beef cattle in tropical pastures increases the nutrient intake but decreases FDMI. The performance also increases with the supplementation plan; however, the growth rate is affected by the grazing season.
\end{abstract}

Key words: Beef calves. Nellore. Supplement. Tropical forage.

1 Profs. Drs., Faculdade de Agronomia e Zootecnia, Departamento de Zootecnia e Extensão Rural, Universidade Federal do Mato Grosso, UFMT, Cuiabá, MT, Brasil. E-mail: nelcinodepaula@hotmail.com; liviavieiradebarros@gmail.com

2 Profs. Drs., Departamento de Zootecnia, Universidade Federal de Viçosa, UFV, Viçosa, MG, Brasil. E-mail: mpaulino@ufv.br; detmann@ufv.br

3 Prof. Dr., Departamento de Produção Animal, Universidade Federal de Goiás, UFG, Goiânia, GO, Brasil. E-mail: victorzootecnista@ufg.br

4 Zootecnista, Fazenda Olhos Verdes, Campo Grande, MS, Brasil. E-mail: ivanfmaciel@yahoo.com.br

5 Discente de Pós-Doutorado, Departamento de Zootecnia, UFV, Viçosa, MG, Brasil. E-mail: sidneyufv@hotmail.com

6 Prof. Dr., Departamento de Zootecnia, Universidade Estadual do Oeste do Paraná, UNIOESTE, Marechal Cândido Rondon, PR, Brasil. E-mail: eritonvalente@yahoo.com.br

7 Prof. Dr., Faculdade de Medicina Veterinária, UFMT, Cuiabá, MT, Brasil. E-mail: joanis@ufmt.br

8 Pesquisador, Centro de Pesquisa Nutripura, Rondonópolis, MT, Brasil. E-mail: leandro_martins@yahoo.com.br

Author for correspondence

Received: Sept. 28, 2018 - Approved: Apr. 01, 2019 


\section{Resumo}

Este estudo foi conduzido para avaliar os efeitos de diferentes planos de suplementação sobre o consumo de nutrientes, digestibilidade aparente total, comportamento ingestivo, crescimento e características de carcaça de bovinos de corte de 4 a 18 meses de idade, em pastejo. Os animais foram mantidos em pastagem com Brachiaria decumbens em quatro períodos: transição águas-seca, seca, transição secaáguas e águas. Quarenta e quatro animais (11 por tratamento) foram distribuídos aleatoriamente em um dos quatro planos nutricionais de suplementação definidos pela quantidade de suplemento ofertada: controle (somente mistura mineral), baixo, médio e alto plano de suplementação. Não houve diferença $(\mathrm{P}>0,10)$ no consumo de matéria seca $(\mathrm{CMS})$. No entanto, os animais que receberam médio e alto plano de suplementação reduziram $(\mathrm{P}<0,10)$ o consumo de matéria seca de forragem $(\mathrm{CMSF})$ comparado ao controle e baixo plano. O CMS e CMSF foram menores $(\mathrm{P}<0,10)$ durante o período seco. Durante a estação chuvosa, o tempo de pastejo reduziu $(\mathrm{P}<0,10)$ para os animais que receberam suplementação em comparação ao controle, mas foi semelhante entre os planos médio e alto. O desempenho e as características de carcaça foram maiores $(\mathrm{P}<0,10)$ para o alto e médio plano comparados ao baixo e controle. Conclui-se que o aumento nas suplementações para bovinos de corte em pastagens tropicais aumenta a ingestão de nutrientes, mas diminui o consumo de forragem. O desempenho também aumenta com o plano de suplementação; no entanto, a taxa de crescimento é afetada pela época do ano.

Palavras-chave: Bezerros. Forragem tropical. Nelore. Suplemento.

\section{Introduction}

Beef cattle breeding in tropical regions primarily uses forage as the main nutrient source. However, tropical grasses rarely provide a balanced diet for grazing cattle because they have nutritional constraints that limit pasture intake, digestibility (DETMANN et al., 2014), and growth performance. There is a large oscillation in animal performance over the course of the year due to periods when the nutritional quality of grasses is better, usually during the rainy season, and periods when low nutrient input (especially of protein) limits the animal growth, often in the dry season. Supplementation is the main nutritional tool for adjusting the imbalance in tropical grasses and increasing the growth rate of beef cattle (DETMANN et al., 2014; LAZZARINI et al., 2009). Several studies have reported the positive effects of supplementation on intake, digestibility, and performance (BOHNERT et al., 2011; DETMANN et al., 2014; FIGUEIRAS et al., 2010; LAZZARINI et al., 2009; PATINO et al., 2015). Routinely, the crude protein (CP) content of the forage is considered as the basis for the animal response to supplementation.
Most studies with beef cattle obtained under grazing conditions notably focus on a particular life stage of the animal, especially periods of low availability and quality of forage (dry season); this makes it difficult to explain the responses to supplementation observed in different studies, even when the forage and supplements are the same, due to the strong influence of previous nutritional plans (DEL CURTO et al., 1990). There is, therefore, a need for further knowledge on the nutritional base that can influence the animal response throughout the different stages of production and the possible relations with the seasonality of the forage. The hypothesis was that increasing in supplementation plan increase the nutrients intake and growing performance, but reduce forage intake, principally in the dry season.

Hence, the aim of the study was to evaluate the effect of supplementation plans on the nutritional parameters, grazing behavior, growth performance, and carcass traits of beef cattle in tropical pastures, from the period of suckling to the age of 18 months. 


\section{Materials and Methods}

The experimental protocol and procedures of this study were approved by the Universidade Federal de Viçosa Committee on Animal Care and Use (Brazil).

\section{Location, animals, and supplementation plans}

This study was carried out at the Beef Cattle Facility of the Universidade Federal de Viçosa in Viçosa, MG, Brazil. The beef calves were evaluated continuously during four phases: 1 , suckling phase, in the rainy-dry transition season (112 d); 2 , growing phase, in the dry season (85 d); 3, growing phase, in the dry-rainy transition season (98 d), and 4 , finishing phase, in the rainy season (130 d). The suckling phase started with 44 Nellore non-castrated beef calves (132.5 $\pm 5.4 \mathrm{~kg}$ body weight (BW) and 90-150 d old), all fed by their respective dams. The growing phase (in the dry season, after weaning for an average of 8 months) included 40 young bulls from the suckling phase. In the growing phase (dryrainy transition season), 36 young bulls remained from the anterior phase. In the finishing phase (rainy season), 28 young bulls remained from the growing phase (dry-rainy transition season). The differences in the number of animals were due to some animals being randomly withdrawn from their groups and used in other studies.

In phase 1 , the experimental area consisted of paddocks of 10 ha each with signal grass (Brachiaria decumbens); in the other phases, each paddock covered 2.5 ha. The drinkers and feeders in each paddock were shaded with asbestos tiles. In the suckling phase, a creep feeder was provided for the calves. Before of the study the pasture was fertilized with $40 \mathrm{~kg} \mathrm{~N} \mathrm{ha}^{-1}$. A continuous grazing method with fix stocking rate was utilized (ALLEN et al., 2011), with all paddocks provided forage ad libitum to animals. To minimize possible effects of paddocks on experimental treatments, the animals were rotated among the paddocks every seven days.
At the beginning of the trial, after measurement of the initial BW, each animal was randomly assigned to one of four nutritional plans of supplementation: CONTROL (only mineral mixture), LOW, MEDIUM, and HIGH concentrate supplementation intake (Table 1). The nutritional plan assigned to each animal at the beginning of the experiment was used in all other experimental phases so as to observe the cumulative and residual effects of each treatment.

\section{Handling, measurements, and samples}

The supplements were formulated to provide $300 \mathrm{~g}$ of CP kg-1 of natural matter in the rainy-dry transition, dry, and dry-rainy transition seasons (Table 1). In the rainy season, $240 \mathrm{~g}$ of CP $\mathrm{kg}^{-1}$ of natural matter supplements were provided (Table 1). The supplements were offered daily at $10 \mathrm{~h} 00$.

At the beginning and end of each phase, the animals were weighed after $14 \mathrm{~h}$ of fasting. The final BW (FBW) and average daily gain (ADG) were obtained at each phase. Every 28 days, the animals were weighed without previous fasting to monitor their growth.

Every 28 days, forage samples were randomly taken to evaluate the forage mass. In each experimental paddock, four forage samples were collected by using a metal square $(0.5 \times 0.5 \mathrm{~m})$ and cutting at ground level. The samples were weighed and homogenized, and forage subsamples (300 g) were taken. To evaluate the chemical composition of the forage consumed, samples were collected with the hand-plucking method every 28 days. The forage samples were dried at $55 \pm 5{ }^{\circ} \mathrm{C}$ for $72 \mathrm{~h}$ and then ground to pass through a $1-$ and 2-mm screen sieve.

To evaluate intake and digestibility by the young bulls (phase 1, 2, 3 and 4), and cows (phase 1), a digestion trial was carried out. The fecal dry matter excretion was determined by using chromic oxide $\left(\mathrm{Cr}_{2} \mathrm{O}_{3}\right)$ as an external marker (DETMANN 
et al., 2001). To estimate the individual intake of supplement, the animals received the supplement with titanium dioxide $\left(\mathrm{TiO}_{2}\right)$ added (TITGEMEYER et al., 2001). The recovery rate of the $\mathrm{TiO}_{2}$ was of $95 \%$. The forage intake was estimated with indigestible neutral detergent fibre (iNDF) as an internal marker (DETMANN et al., 2001).

Table 1. Supplementation plans, ingredients and chemical composition of supplements offered during the experiment.

\begin{tabular}{|c|c|c|c|c|}
\hline & \multicolumn{4}{|c|}{ Seasons } \\
\hline & Rainy-dry & Dry & Dry-rainy & Rainy \\
\hline \multicolumn{5}{|c|}{ Supplementation plans, $\mathrm{kg}$ animal $^{-1}$ day $^{-1}$} \\
\hline Control $^{*}$ & - & - & - & - \\
\hline Low & 0.250 & 0.500 & 0.500 & 0.750 \\
\hline Medium & 0.500 & 1.000 & 1.000 & 1.500 \\
\hline High & 1.000 & 2.000 & 2.000 & 3.000 \\
\hline \multicolumn{5}{|l|}{ Ingredients, $\%$ of fresh matter } \\
\hline Soybean meal & 55.0 & 39.1 & 39.1 & 30.7 \\
\hline Ground corn & 22.5 & 29.0 & 29.0 & 33.5 \\
\hline Ground sorghum & 22.5 & 29.0 & 29.0 & 33.5 \\
\hline Urea:amonia sulfate $(9: 1)$ & - & 2.9 & 2.9 & 2.3 \\
\hline \multicolumn{5}{|l|}{ Chemical composition, \% DM } \\
\hline Organic matter & 96.15 & 96.62 & 96.44 & 97.19 \\
\hline Crude protein & 32.12 & 32.95 & 32.55 & 28.02 \\
\hline Ether extract & 2.10 & 2.03 & 2.03 & 2.07 \\
\hline NDFap & 11.04 & 10.19 & 10.92 & 9.92 \\
\hline Non-fibrous carbohydrates & 50.90 & 56.62 & 56.17 & 61.32 \\
\hline
\end{tabular}

* $=$ Mineral mixture with unrestricted access. NDFap: neutral detergent fiber corrected for ash and protein.

Each digestion trial lasted nine days, with the first six days intended for the adaptation of the animals to $\mathrm{Cr}_{2} \mathrm{O}_{3}$ and $\mathrm{TiO}_{2}$, and the three remaining days for collecting samples. The $\mathrm{TiO}_{2}$ was added to the supplement daily. Chromic oxide was packed in paper cartridges and applied into the esophagus by using a rubber tube. On days 7,8 , and 9, fecal samples were collected directly from the rectum of the animals at $16 \mathrm{~h} 00,12 \mathrm{~h} 00$, and $08 \mathrm{~h} 00$, respectively. The fecal samples were dried and ground to passed through a 1- or 2-mm screen and then were proportionally subsampled into a composite sample. The same procedure was applied in the digestion trial of the remaining experimental phases.
On day 28 of the second period of the suckling phase, the milk intake of calves was estimated. The calves were separated from their mothers for $12 \mathrm{~h}$ (18h00 to 06h00). By using an application of oxytocin, milking was performed manually by a previously trained employee. The times each cow was milked were recorded, and then milk yield was converted to 24-hour-milk-yield. Additionally, milk samples were sent to the milk quality laboratory for chemical composition analysis. The average milk composition was $40.4 \pm 7,38.7 \pm 2.1,44 \pm 0.9$ and $135 \pm 3.3$ for protein, fat, lactose and dry extract. 


\section{Chemical analyses}

For forage samples obtained by hand-plucking, the supplements and feces were evaluated to determine their DM, organic matter (OM), CP, lignin $(72 \% \mathrm{w} / \mathrm{w}$ sulfuric acid), and ether extract (EE) contents according to the AOAC (1990) methods. In the neutral detergent fiber (NDF) analysis, the samples were treated with a heat-stable alphaamylase, without using sodium sulfite, and corrected for residual ash (MERTENS, 2002). The NDF was also corrected for nitrogenous compounds content as described by Licitra et al. (1996), constituting the NDF corrected for ash and protein (NDFap).

The fecal samples and chromic oxide were analyzed for chromium concentration by using an atomic absorption spectrophotometer. In addition, the fecal samples and titanium dioxide were analyzed for titanium concentration by colorimetry according to Detmann et al. (2012).

The voluntary dry matter intake estimates were obtained by using the iNDF content as an internal marker, quantified by in situ incubation for $288 \mathrm{~h}$ (VALENTE et al., 2011).

\section{Grazing behavior}

The diurnal grazing behavior of young bulls was monitored twice in the dry-rainy transition season and thrice in the rainy season by human observation with the aid of binoculars. All animals were observed continuously for $12 \mathrm{~h}$ (from $06 \mathrm{~h} 00$ to $18 \mathrm{~h} 00$ ). Individual young bulls were observed during periods of grazing, ruminating, idling, and trough stay eating time. Observations were made by at least four persons, two of whom observed the animals, while the other two recorded the information in a spreadsheet. The time that each animal changed the activity was noted and later the time of each activity was computed.

\section{Slaughter and body composition}

The animals were desensitized by using a cash knocker and killed through exsanguination by applying conventional humane procedures. All the body components were cleaned and weighed. These included the internal organs (lungs, heart, kidneys, trachea, liver, reproductive tract, and spleen), digestive tract (rumen, reticulum, omasum, abomasum, and small and large intestines), kidneypelvic-heart fat, visceral fat, tongue, tail, hide, head, feet, and carcass. The empty BW (EBW) was computed as the sum of all body components.

The carcass of each animal was split into two identical, longitudinal halves. The half carcasses were weighed hot and then chilled at $-1{ }^{\circ} \mathrm{C}$. After $24 \mathrm{~h}$ of chilling, the carcasses were again weighed to obtain the chilled carcass weight. After measuring the fat thickness at the 12th rib, the right half carcass was physically separated into fat, muscle, and bone. All components were weighed.

\section{Statistical analysis}

The variables were analyzed in a completely randomized design. The arrangement of treatments followed a $4 \times 4$ factorial design (four supplementation plans and four seasons) that used repeated measures with mixed models, considering the effect of the nutritional plan (fixed effect), the effect of the season (fixed effect), the effect of the animal nested within the nutritional plan and season (random effect), and the interaction between the main effects (fixed effect).

The PROC MIXED procedure of SAS version 9.3 (SAS Institute Inc., Cary, NC, USA) was used. For the analysis of the variables, the structures of the matrix of error covariance were adjusted. Among the investigated structures, the best according to the Bayesian information criterion was compound symmetric. After carrying out ANOVA, comparisons between means were done by applying Fisher's protected LSD. Statistical significance was set at $\mathrm{P}<0.10$. 


\section{Results}

Available Forage and Chemical Composition

The average forage masses available were $4.72,4.96,4.00$, and $5.14 \mathrm{t} \mathrm{ha}^{-1}$ in the rainy-dry transition, dry, dry-rainy transition, and rainy seasons, respectively. The proportion of green leaf was greater during the rainy season, representing $22.4 \%$ of the total DM available, compared with 15,12 , and $20 \%$ in the rainy-dry, dry, and dry-rainy seasons, respectively. In addition, the evolution of maturity stage forage increased the ratio of dry leaf to green leaf. The proportion of dry leaf during the dry season was $23 \%$ of the total DM available compared with 15,13 , and $12 \%$ in the rainy-dry, dry-rainy, and rainy seasons, respectively. The $\mathrm{CP}$ content of the forage was affected by the season, with $10.10,7.99,8.1$, and $11.15 \%$ in the rainydry, dry, dry-rainy, and rainy seasons, respectively (Table 2).

Table 2. Chemical composition of the pasture (Brachiaria decumbens) collected during the experimental seasons.

\begin{tabular}{lcccc}
\hline & \multicolumn{4}{c}{ Seasons } \\
\cline { 2 - 5 } & Rainy-dry & Dry & Dry-rainy & Rainy \\
\hline Forage composition, \% DM DM $^{*}$ & & & & \\
Dry Matter & $28.24 \pm 1.23$ & $28.68 \pm 0.74$ & $30.64 \pm 2.30$ & $24.74 \pm 0.80$ \\
Organic matter & $91.00 \pm 2.80$ & $90.19 \pm 3.00$ & $91.22 \pm 1.9$ & $92.52 \pm 2.5$ \\
Crude protein & $10.09 \pm 0.50$ & $7.99 \pm 0.59$ & $8.10 \pm 0.64$ & $11.15 \pm 0.56$ \\
Ether extract & $1.01 \pm 0.04$ & $0.60 \pm 0.03$ & $0.64 \pm 0.02$ & $1.03 \pm 0.07$ \\
Neutral detergent fiber & $55.84 \pm 1.24$ & $56.97 \pm 1.60$ & $60.05 \pm 0.95$ & $53.79 \pm 3.01$ \\
Non-fibrous carbohydrates & $24.06 \pm 0.83$ & $24.64 \pm 0.75$ & $22.44 \pm 0.76$ & $26.55 \pm 0.84$ \\
Lignin & $3.21 \pm 0.28$ & $3.87 \pm 0.80$ & $2.73 \pm 0.43$ & $3.03 \pm 0.16$ \\
\hline
\end{tabular}

${ }^{*}=$ Obtained by handle plucked sampling. ${ }^{\dagger}=\%$ fresh matter.

\section{Intake}

The average milk intake by calves was $3.7 \pm$ $1.94 \mathrm{~kg} \mathrm{~d}^{-1}$.

There was no difference $(\mathrm{P}>0.10)$ for DM intake (DMI) of suckling cows. The average was $21.33 \pm$ $1.01 \mathrm{~g} \mathrm{~kg}^{-1} \mathrm{BW}$.

Because of the large differences in the growth rate of young bulls during the production phases, intake was expressed as a function of average BW (taken on first and last day of each digestion trial), allowing a suitable comparison between supplementation plans (VALENTE et al., 2014).

There was no interaction $(\mathrm{P}>0.10)$ between supplementation plan and season regarding DMI, forage DM intake (FDMI), NDF intake (NDFI), and CP intake (CPI) (Tables 3 and 4).
The supplementation plan had no effect (P $>0.10)$ on DMI but influenced $(\mathrm{P}<0.10)$ FDMI (Table 3). During the rainy-dry transition season, FDMI was lower $(\mathrm{P}<0.10)$ for animals under medium and high supplementation compared with those under low and non-supplementation (Table 3 ). The coefficients of substitution indicated that for each gram of supplement $\mathrm{kg}^{-1} \mathrm{BW}$, there were decreases of 0.86 and $0.84 \mathrm{~g}$ of forage for medium and high supplementation, respectively (Table 3). During the dry season, FDMI also decreased $(\mathrm{P}<$ $0.10)$ with supplementation, indicating that under high supplementation, FDMI was the most affected (11.44 $\mathrm{g} \mathrm{kg}^{-1} \mathrm{BW}$ ); decreases of 25.4, 32.6, and $40.3 \%$ were observed for animals under medium, low, and control supplementation, respectively (Table 3). Similarly, during the rainy season, the 
higher supplementation plans also affected FDMI more severely. For each gram of supplementkg-1 of BW, there were decreases of 0.81 and $0.47 \mathrm{~g}$ of forage for medium and high supplementation, respectively. Nonetheless, low supplementation increased FDMI by $0.57 \mathrm{~g}$ (Table 3). DMI and FDMI were found to be lower $(\mathrm{P}<0.10)$ in the dry season than in the other seasons.

The supplementation plan was observed to have an effect $(\mathrm{P}<0.10)$ on NDFI. During the rainydry transition and dry seasons, NDFI was lower $(\mathrm{P}<0.10)$ for animals under medium and high supplementation compared with those under low and non-supplementation; no differences were found during the dry-rainy season (Table 4). During the rainy season, NDFI was greater $(\mathrm{P}<0.10)$ for low supplementation; however, no differences were observed for animals under non- and high supplementation (Table 4). NDFI was lower $(\mathrm{P}<$ $0.10)$ in the dry season than in all the other seasons (Table 4).

CPI was greater $(\mathrm{P}<0.10)$ in young bulls that received supplementation than in non-supplemented animals; those under high supplementation showed the highest CPI, those under low and medium supplementation had intermediate CPI, and nonsupplemented animals had the least CPI (Table 4). CPI was observed to be lower $(\mathrm{P}<0.10)$ in the dry and dry-rainy seasons than in all the other seasons, except for animals under high supplementation, which had lower CPI in the rainy season (Table 4).

\section{Digestibility}

Significant interactions $(\mathrm{P}<0.10)$ between supplementation plan and season were observed regarding digestibility of $\mathrm{DM}, \mathrm{CP}, \mathrm{NDF}$, and total digestible nutrients (TDN) (Table 5). DM digestibility (DMD) and CP digestibility (CPD) were greater $(\mathrm{P}<0.10)$ for animals under high supplementation, intermediate for those under medium and low supplementation, and low for non-supplemented animals, except in the rainy season, during which no differences $(\mathrm{P}>0.10)$ were observed (Table 5). The young bulls that received supplementation had higher $(\mathrm{P}<0.10)$ TDN content compared with non-supplemented animals; such content was greater for animals under high supplementation and intermediate for those under low and medium supplementation (Table 5). NDF digestibility (NDFD) was higher $(\mathrm{P}<0.10)$ in the rainy-dry transition season, intermediate in the dryrainy and rainy seasons, and lower in the dry season. CPD was lower $(\mathrm{P}<0.10)$ in the dry-rainy transition season under all supplementation plans (Table 5). 
Table 3. Effect of supplementation plans on dry matter intake, dry matter forage intake and coefficient of substitution in beef cattle on pasture.

\begin{tabular}{|c|c|c|c|c|c|c|c|c|c|}
\hline \multirow[b]{2}{*}{ Trait } & \multirow[b]{2}{*}{ Seasons* } & \multicolumn{4}{|c|}{ Supplementation plans } & \multirow[b]{2}{*}{ SEM } & \multicolumn{3}{|c|}{$P$-value } \\
\hline & & Control & Low & Medium & High & & Plan & Season & $\begin{array}{l}\text { Plan } \times \\
\text { Season }\end{array}$ \\
\hline \multicolumn{10}{|c|}{$\begin{array}{l}\text { Dry matter intake, } \\
\mathrm{g} \mathrm{kg}^{-1} \mathrm{BW}\end{array}$} \\
\hline & Rainy-dry & $25.27^{\mathrm{a}}$ & $25.90^{\mathrm{a}}$ & $23.49^{\mathrm{a}}$ & $23.99^{\mathrm{a}}$ & 1.25 & \multirow{4}{*}{0.509} & \multirow{4}{*}{$<0.001$} & \multirow{4}{*}{0.618} \\
\hline & Dry & $19.16^{\mathrm{b}}$ & $19.10^{\mathrm{c}}$ & $18.82^{\mathrm{b}}$ & $18.78^{\mathrm{b}}$ & 1.31 & & & \\
\hline & Dry-rainy & $20.07^{\mathrm{b}}$ & $21.35^{\mathrm{bc}}$ & $22.87^{\mathrm{a}}$ & $22.60^{\mathrm{a}}$ & 1.38 & & & \\
\hline & Rainy & $20.61^{\mathrm{b}}$ & $23.93^{\mathrm{ab}}$ & $21.34^{\mathrm{ab}}$ & $24.12^{\mathrm{a}}$ & 1.57 & & & \\
\hline \multicolumn{10}{|c|}{$\begin{array}{l}\text { Dry matter forage intake, } \\
\mathrm{g} \mathrm{kg}^{-1} \mathrm{BW}\end{array}$} \\
\hline & Rainy-dry & $22.81^{\mathrm{Aa}}$ & $21.42^{\mathrm{Aa}}$ & $18.68^{\mathrm{Ba}}$ & $16.65^{\mathrm{Ba}}$ & 1.11 & \multirow{4}{*}{$<0.001$} & \multirow{4}{*}{$<0.001$} & \multirow{4}{*}{0.533} \\
\hline & Dry & $19.17^{\mathrm{Ab}}$ & $16.98^{\mathrm{ABb}}$ & $15.33^{\mathrm{Bb}}$ & $11.44^{\mathrm{Cb}}$ & 1.17 & & & \\
\hline & Dry-rainy & $20.09^{\mathrm{Aab}}$ & $19.52^{\mathrm{ABab}}$ & $19.68^{\mathrm{Aa}}$ & $16.70^{\mathrm{Ba}}$ & 1.23 & & & \\
\hline & Rainy & $20.66^{\mathrm{ABab}}$ & $21.84^{\mathrm{Aa}}$ & $17.69^{\mathrm{Bab}}$ & $17.56^{\mathrm{Ba}}$ & 1.41 & & & \\
\hline \multicolumn{10}{|c|}{$\begin{array}{l}\text { Substitution coefficient, } g \\
\text { supplement } \mathrm{g}^{-1} \text { forage }\end{array}$} \\
\hline & Rainy-dry & - & -0.31 & -0.86 & -0.84 & - & \multirow{4}{*}{-} & \multirow{4}{*}{-} & \multirow{4}{*}{-} \\
\hline & Dry & - & -1.03 & -1.10 & -1.05 & - & & & \\
\hline & Dry-rainy & - & -0.31 & -0.13 & -0.57 & - & & & \\
\hline & Rainy & - & 0.57 & -0.81 & -0.47 & - & & & \\
\hline
\end{tabular}

$*$ Rainy-dry, $\mathrm{n}=44$; Dry, N n 40; Dry-rainy, $\mathrm{n}=36$; Rainy, $\mathrm{n}=28$.

abc - values with different capital letters in the same row and different lowercase letters in the same column differ significantly at $\mathrm{P}<0.10$.

Table 4. Effect of supplementation plans on intake of neutral detergent fiber and crude protein in beef cattle on pasture.

\begin{tabular}{|c|c|c|c|c|c|c|c|c|c|}
\hline \multirow[b]{2}{*}{ Trait } & \multirow[b]{2}{*}{ Seasons* } & \multicolumn{4}{|c|}{ Supplementation plans } & \multirow[b]{2}{*}{ SEM } & \multicolumn{3}{|c|}{$P$-value } \\
\hline & & Control & Low & Medium & High & & Plan & Season & $\begin{array}{l}\text { Plan } \times \\
\text { Season }\end{array}$ \\
\hline \multicolumn{10}{|c|}{$\begin{array}{l}\text { Neutral detergent fibre } \\
\text { intake } \mathrm{g} \mathrm{kg}^{-1} \mathrm{BW}\end{array}$} \\
\hline & Rainy-dry & $12.73^{\mathrm{Aa}}$ & $12.11^{\mathrm{ABa}}$ & $10.72^{\mathrm{BCab}}$ & $9.88^{\mathrm{Ca}}$ & 0.64 & \multirow{4}{*}{0.003} & \multirow{4}{*}{$<0.001$} & \multirow{4}{*}{0.603} \\
\hline & Dry & $10.92^{\mathrm{Ab}}$ & $9.88^{\mathrm{ABb}}$ & $9.10^{\mathrm{Bc}}$ & $7.31^{\mathrm{Cb}}$ & 0.68 & & & \\
\hline & Dry-rainy & $12.06^{\mathrm{Aab}}$ & $11.92^{\mathrm{Aa}}$ & $12.17^{\mathrm{Aa}}$ & $10.71^{\mathrm{Aa}}$ & 0.71 & & & \\
\hline & Rainy & $11.11^{\mathrm{ABab}}$ & $11.96^{\mathrm{Aa}}$ & $9.90^{\mathrm{Bbc}}$ & $10.16^{\mathrm{ABa}}$ & 0.81 & & & \\
\hline \multicolumn{10}{|c|}{$\begin{array}{l}\text { Crude protein intake } \mathrm{g} \\
\mathrm{kg}^{-1} \mathrm{BW}\end{array}$} \\
\hline & Rainy-dry & $3.00^{\mathrm{Ca}}$ & $3.43^{\mathrm{Ba}}$ & $3.30^{\mathrm{BCa}}$ & $3.91^{\mathrm{Aa}}$ & 0.194 & \multirow{4}{*}{$<0.001$} & \multirow{4}{*}{$<0.001$} & \multirow{4}{*}{0.308} \\
\hline & Dry & $1.52^{\mathrm{Cc}}$ & $1.98^{\mathrm{Bc}}$ & $2.31^{\mathrm{Bc}}$ & $3.26^{\mathrm{Ab}}$ & 0.213 & & & \\
\hline & Dry-rainy & $1.61^{\mathrm{Dc}}$ & $2.12^{\mathrm{Cc}}$ & $2.58^{\mathrm{Bbc}}$ & $3.20^{\mathrm{Ab}}$ & 0.193 & & & \\
\hline & Rainy & $2.27^{\mathrm{Cb}}$ & $2.96^{\mathrm{Ab}}$ & $2.97^{\text {Aab }}$ & $2.73^{\mathrm{Bc}}$ & 0.151 & & & \\
\hline
\end{tabular}

${ }^{*}=$ Rainy-dry, $\mathrm{n}=44 ;$ Dry, $\mathrm{n}=40$; Dry-rainy, $\mathrm{n}=36$; Rainy, $\mathrm{n}=28$.

abc - Values with different capital letters in the same row and different lowercase letters in the same column differ significantly at $\mathrm{P}<0.10$. 
Table 5. Effect of supplementation plans on total tract apparent digestibility and total digestible nutrients in beef cattle on pasture.

\begin{tabular}{|c|c|c|c|c|c|c|c|c|c|}
\hline \multirow{2}{*}{ Trait } & \multirow[b]{2}{*}{ Seasons* } & \multicolumn{4}{|c|}{ Supplementation plans } & \multirow{2}{*}{ SEM } & \multicolumn{3}{|c|}{$P$-value } \\
\hline & & Control & Low & Medium & High & & Plan & Season & Plan $\times$ Season \\
\hline \multicolumn{10}{|c|}{$\begin{array}{l}\text { Dry matter digestibility, } \mathrm{g} \\
\mathrm{kg}^{-1} \mathrm{DM}\end{array}$} \\
\hline & Rainy-dry & $633.5^{\mathrm{Ca}}$ & $676.7^{\mathrm{Ba}}$ & $653.4^{\mathrm{Ba}}$ & $711.4^{\mathrm{Aa}}$ & 8.89 & \multirow{4}{*}{$<0.001$} & \multirow{4}{*}{$<0.001$} & \multirow{4}{*}{0.008} \\
\hline & Dry & $515.1^{\mathrm{Cb}}$ & $566.8^{\mathrm{Bc}}$ & $570.3^{\mathrm{Bc}}$ & $618.6^{\mathrm{Abc}}$ & 9.32 & & & \\
\hline & Dry-rainy & $503.4^{\mathrm{Cb}}$ & $544.0^{\mathrm{Bd}}$ & $531.9^{\mathrm{Bd}}$ & $601.1^{\mathrm{Ac}}$ & 9.77 & & & \\
\hline & Rainy & $613.5^{\mathrm{Aa}}$ & $616.7^{\mathrm{Ab}}$ & $624.2^{\mathrm{Ab}}$ & $635.1^{\mathrm{Ab}}$ & 10.91 & & & \\
\hline \multicolumn{10}{|c|}{$\begin{array}{l}\text { Crude protein digestibility, } \\
\mathrm{g} \mathrm{kg}^{-1} \mathrm{DM}\end{array}$} \\
\hline & Rainy-dry & $627.1^{\mathrm{Ca}}$ & $691.3^{\mathrm{Ba}}$ & $688.7^{\mathrm{Ba}}$ & $727.9^{\text {Аа }}$ & 15.00 & \multirow{4}{*}{$<0.001$} & \multirow{4}{*}{$<0.001$} & \multirow{4}{*}{$<0.001$} \\
\hline & Dry & $459.5^{\mathrm{cb}}$ & $592.3^{\mathrm{Bb}}$ & $628.0^{\mathrm{Bb}}$ & $730.1^{\mathrm{Aa}}$ & 15.74 & & & \\
\hline & Dry-rainy & $298.9^{\mathrm{Cc}}$ & $465.1^{\mathrm{Bc}}$ & $447.9^{\mathrm{Bc}}$ & $619.5^{\mathrm{Ac}}$ & 16.60 & & & \\
\hline & Rainy & $655.4^{\mathrm{ABa}}$ & $630.7^{\mathrm{Bb}}$ & $644.4^{\mathrm{ABab}}$ & $684.7^{\mathrm{Ab}}$ & 18.87 & & & \\
\hline \multicolumn{10}{|c|}{$\begin{array}{l}\text { Neutral detergent fiber } \\
\text { digestibility } \mathrm{g} \mathrm{kg}^{-1} \mathrm{DM}\end{array}$} \\
\hline & Rainy-dry & $660.3^{\mathrm{a}}$ & $693.0^{\mathrm{a}}$ & $676.0^{\mathrm{a}}$ & $687.9^{\mathrm{a}}$ & 7.79 & \multirow{4}{*}{0.332} & \multirow{4}{*}{$<0.001$} & \multirow{4}{*}{0.003} \\
\hline & Dry & $573.1^{\mathrm{c}}$ & $602.1^{\mathrm{c}}$ & $605.8^{\mathrm{c}}$ & $566.4^{\mathrm{d}}$ & 8.16 & & & \\
\hline & Dry-rainy & $637.4^{\mathrm{b}}$ & $626.5^{\mathrm{b}}$ & $630.3^{\mathrm{b}}$ & $639.2^{\mathrm{b}}$ & 8.58 & & & \\
\hline & Rainy & $638.9^{b}$ & $630.1^{\mathrm{b}}$ & $624.2^{\mathrm{bc}}$ & $608.0^{c}$ & 9.65 & & & \\
\hline \multicolumn{10}{|c|}{$\begin{array}{l}\text { Total digestible nutrients, } \\
\mathrm{g} \mathrm{kg}^{-1} \mathrm{DM}\end{array}$} \\
\hline & Rainy-dry & $607.2^{\mathrm{Da}}$ & $652.8^{\mathrm{Ba}}$ & $627.0^{\mathrm{Ca}}$ & $675.2^{\mathrm{Aa}}$ & 8.29 & \multirow{4}{*}{$<0.001$} & \multirow{4}{*}{$<0.001$} & \multirow{4}{*}{$<0.001$} \\
\hline & Dry & $492.2^{\mathrm{Cc}}$ & $547.0^{\mathrm{Bc}}$ & $565.2^{\mathrm{Bb}}$ & $628.0^{\mathrm{Abc}}$ & 8.67 & & & \\
\hline & Dry-rainy & $511.1^{\mathrm{Cb}}$ & $546.3^{\mathrm{Bc}}$ & $543.4^{\mathrm{Bc}}$ & $612.1^{\mathrm{Ac}}$ & 9.08 & & & \\
\hline & Rainy & $598.0^{\mathrm{Ca}}$ & $606.5^{\mathrm{BCb}}$ & $624.6^{\mathrm{ABa}}$ & $639.4^{\mathrm{Ab}}$ & 10.11 & & & \\
\hline
\end{tabular}

${ }^{*}=$ Rainy-dry, $\mathrm{n}=44$; Dry, $\mathrm{n}=40$; Dry-rainy, $\mathrm{n}=36$; Rainy, $\mathrm{n}=28$.

abc - Values with different capital letters in the same row and different lowercase letters in the same column differ significantly at $\mathrm{P}<0.10$.

\section{Grazing behavior}

An interaction $(\mathrm{P}<0.10)$ between supplementation plan and season was found only for grazing time. However, supplementation plan and season were found to have an effect $(\mathrm{P}<0.10)$ on all variables (Table 6 ). Grazing time was not influenced $(\mathrm{P}>0.10)$ by supplementation plan during the dryrainy transition season, but the ruminating time was lower $(\mathrm{P}<0.10)$ for young bulls under medium and high supplementation compared with those under low and non-supplementation. In this season, young bulls under supplementation spent more time $(\mathrm{P}<$ $0.10)$ on trough stay than did non-supplemented animals, with a longer time recorded for high supplementation and an intermediate amount of time for medium and low supplementation. During the rainy season, the grazing time decreased $(\mathrm{P}<$ $0.10)$ with the supplementation plan. Compared with non-supplemented animals, young bulls receiving supplementation spent more time (P $<0.10)$ resting. The trough stay time was also increased for young bulls on supplementation. The grazing time was greater $(\mathrm{P}<0.10)$ in the dry-rainy transition season compared with the rainy season under the supplementation plans; no difference was observed in non-supplemented animals $(\mathrm{P}>0.10)$. 
The grazing time is inversely proportional to the idle time. The trough stay time was greater $(\mathrm{P}<0.10)$ in the rainy season under all supplementation plans.

\section{Performance and carcass characteristics}

Significant interactions $(\mathrm{P}<0.10)$ between supplementation plan and season were detected for FBW and ADG (Table 7). During the rainydry transition season, ADG was greater $(\mathrm{P}<0.10)$ for animals under high supplementation compared with those under control, low, and medium supplementation and was similar $(\mathrm{P}<0.10)$ between control, low, and medium supplementation; no differences $(\mathrm{P}>0.10)$ in FBW were observed. In the dry and dry-rainy transition seasons, ADG was also greater $(\mathrm{P}<0.10)$ for high supplementation compared with the other plans and was similar ( $\mathrm{P}$ $>0.10$ ) between non- and low supplementation. In the dry-rainy season, FBW was also greater for high supplementation and was similar between control, low, and medium supplementation. In the rainy season, ADG was greater $(\mathrm{P}<0.10)$ for high and medium supplementation compared with low supplementation; non-supplemented animals had a similar ADG to those under medium supplementation. FBW was greater for high supplementation, intermediate for low and medium supplementation, and low for non-supplemented young bulls.

The supplementation plans did not affect $(\mathrm{P}>$ $0.10)$ the carcass muscle, carcass fat, and LM area $\left(\mathrm{cm}^{2} \mathrm{~kg}^{-1}\right)$; however, the EBW, hot carcass weight ( $\mathrm{HCW})$, and cold carcass weight (CCW) were greater $(\mathrm{P}<0.10)$ for high and medium supplementation compared with low and non-supplementation, with the latter two showing no differences (Table 8). The hot carcass yield (HCY) and cold carcass yield $(\mathrm{CCY})$ were greater $(\mathrm{P}<0.10)$ for low, medium, and high supplementation compared with nonsupplementation and were similar $(\mathrm{P}<0.10)$ between low, medium, and high supplementation. The carcass bone and LM area $\left(\mathrm{cm}^{2}\right)$ were similar $(\mathrm{P}>0.10)$ between low, medium, and high supplementation, as well as between low and non-supplementation. The body length (BL) was greater $(\mathrm{P}<0.10)$ for medium and high supplementation compared with control and low supplementation.

Table 6. Effect of supplementation plans on grazing behavior of beef cattle.

\begin{tabular}{|c|c|c|c|c|c|c|c|c|c|}
\hline \multirow[b]{2}{*}{ Trait } & \multirow[b]{2}{*}{ Seasons* } & \multicolumn{4}{|c|}{ Supplementation plans } & \multirow{2}{*}{ SEM } & \multicolumn{3}{|c|}{$\mathrm{p}$ Value } \\
\hline & & Control & Low & Medium & High & & Plan & Season & Plan $\times$ Season \\
\hline \multicolumn{10}{|c|}{ Grazing time, $\min$} \\
\hline & Dry-rainy & $373.44^{\mathrm{Aa}}$ & $381.56^{\mathrm{Aa}}$ & $404.33^{\mathrm{Aa}}$ & $382.11^{\mathrm{Aa}}$ & 16.21 & \multirow{2}{*}{0.043} & \multirow{2}{*}{$<0.001$} & \multirow{2}{*}{0.001} \\
\hline & Rainy & $344.00^{\mathrm{Aa}}$ & $281.00^{\mathrm{Bb}}$ & $233.62^{\mathrm{Cb}}$ & $240.24^{\mathrm{BCb}}$ & 18.38 & & & \\
\hline \multicolumn{10}{|c|}{ Ruminating time, min } \\
\hline & Dry-rainy & $136.33^{\mathrm{Aa}}$ & $134.11^{\mathrm{Aa}}$ & $105.44^{\mathrm{Bb}}$ & $67.67^{\mathrm{Cb}}$ & 11.64 & \multirow{2}{*}{0.001} & \multirow{2}{*}{0.001} & \multirow{2}{*}{0.153} \\
\hline & Rainy & $148.52^{\mathrm{Aa}}$ & $154.57^{\mathrm{Aa}}$ & $158.81^{\mathrm{Aa}}$ & $127.86^{\mathrm{Aa}}$ & 13.20 & & & \\
\hline \multicolumn{10}{|c|}{ Idle time, $\min$} \\
\hline & Dry-rainy & $208.11^{\mathrm{Aa}}$ & $189.67^{\mathrm{Bb}}$ & $192.56^{\mathrm{Ab}}$ & $238.22^{\mathrm{Ab}}$ & 20.23 & \multirow{2}{*}{0.037} & \multirow{2}{*}{0.003} & \multirow{2}{*}{0.147} \\
\hline & Rainy & $209.38^{\mathrm{Ba}}$ & $260.38^{\mathrm{ABa}}$ & $292.91^{\mathrm{Aa}}$ & $303.57^{\mathrm{Aa}}$ & 20.94 & & & \\
\hline \multicolumn{10}{|c|}{ Trough stay time, min } \\
\hline & Dry-rainy & $2.11^{\mathrm{Cb}}$ & $14.67^{\mathrm{Bb}}$ & $17.67^{\mathrm{Bb}}$ & $32.00^{\mathrm{Ab}}$ & 3.04 & \multirow{2}{*}{$<0.001$} & \multirow{2}{*}{$<0.001$} & \multirow{2}{*}{0.619} \\
\hline & Rainy & $18.09^{\mathrm{Ca}}$ & $24.05^{\mathrm{Ca}}$ & $34.67^{\mathrm{Ba}}$ & $48.33^{\mathrm{Aa}}$ & 3.44 & & & \\
\hline
\end{tabular}

${ }^{*}=$ Dry-rainy, $\mathrm{n}=36$; Rainy, $\mathrm{n}=28$.

abc - values with different capital letters in the same row and different lowercase letters in the same column differ significantly at $P<0.10$. 
Table 7. Effect of supplementation plans on final body weight, average daily gain, and estimated dry matter intake supplements of beef cattle on pasture.

\begin{tabular}{|c|c|c|c|c|c|c|c|c|c|}
\hline \multirow[b]{2}{*}{ Trait } & \multirow[b]{2}{*}{ Seasons ${ }^{*}$} & \multicolumn{4}{|c|}{ Supplementation plans } & \multirow{2}{*}{ SEM } & \multicolumn{3}{|c|}{$P$-value } \\
\hline & & Control & Low & Medium & High & & Plan & Season & Plan $\times$ Season \\
\hline \multicolumn{10}{|c|}{ Final body weight, $\mathrm{kg}$} \\
\hline & Rainy-dry & $207.0^{\mathrm{d}}$ & $209.4^{\mathrm{d}}$ & $208.8^{\mathrm{d}}$ & $222.9^{d}$ & 11.65 & \multirow{4}{*}{0.038} & \multirow{4}{*}{$<0.001$} & \multirow{4}{*}{$<0.001$} \\
\hline & Dry & $234.3^{\mathrm{Bc}}$ & $241.6^{\mathrm{Bc}}$ & $251.7^{\mathrm{ABc}}$ & $277.3^{\mathrm{Ac}}$ & 13.21 & & & \\
\hline & Dry-rainy & $270.3^{\mathrm{Bb}}$ & $277.8^{\mathrm{Bb}}$ & $298.2^{\mathrm{Bb}}$ & $333.7^{\mathrm{Ab}}$ & 13.62 & & & \\
\hline & Rainy & $359.0^{\mathrm{Ca}}$ & $365.9^{\mathrm{BCa}}$ & $397.5^{\mathrm{Ba}}$ & $443.0^{\mathrm{Aa}}$ & 15.07 & & & \\
\hline \multicolumn{10}{|c|}{ Average daily gain, $\mathrm{kg}$ day $^{-1}$} \\
\hline & Rainy-dry & $0.662^{\mathrm{Ba}}$ & $0.709^{\mathrm{Ba}}$ & $0.668^{\mathrm{Ba}}$ & $0.807^{\mathrm{Aa}}$ & 0.026 & \multirow{4}{*}{$<0.001$} & \multirow{4}{*}{$<.0001$} & \multirow{4}{*}{0.001} \\
\hline & Dry & $0.318^{\mathrm{Cb}}$ & $0.376^{\mathrm{Cc}}$ & $0.505^{\mathrm{Bb}}$ & $0.633^{\mathrm{Ab}}$ & 0.036 & & & \\
\hline & Dry-rainy & $0.363^{\mathrm{Cb}}$ & $0.350^{\mathrm{Cc}}$ & $0.464^{\mathrm{Bb}}$ & $0.560^{\mathrm{Ac}}$ & 0.034 & & & \\
\hline & Rainy & $0.650^{\mathrm{BCa}}$ & $0.627^{\mathrm{cb}}$ & $0.722^{\mathrm{ABa}}$ & $0.776^{\mathrm{Aa}}$ & 0.031 & & & \\
\hline \multicolumn{10}{|c|}{$\begin{array}{l}\text { Estimated dry matter intake } \\
\text { supplement } \mathrm{kg} \mathrm{d}^{-1}\end{array}$} \\
\hline & Rainy-dry & - & 0.261 & 0.483 & 0.925 & - & \multirow{4}{*}{ - } & \multirow{4}{*}{-} & \multirow{4}{*}{-} \\
\hline & Dry & - & 0.498 & 0.886 & 1.855 & - & & & \\
\hline & Dry-rainy & - & 0.490 & 0.937 & 1.820 & - & & & \\
\hline & Rainy & - & 0.724 & 1.407 & 2.704 & - & & & \\
\hline
\end{tabular}

${ }^{*}=$ Rainy-dry, $\mathrm{n}=44$; Dry, $\mathrm{n}=40$; Dry-rainy, $\mathrm{n}=36$; Rainy, $\mathrm{n}=28$.

abcd - values with different capital letters in the same row and different lowercase letters in the same column differ significantly at $P<0.10$.

Table 8. Effect of supplementation plans on for carcass characteristics of beef cattle on pasture.

\begin{tabular}{|c|c|c|c|c|c|c|}
\hline \multirow{3}{*}{ Trait } & \multicolumn{4}{|c|}{ Supplementation plans } & \multirow{3}{*}{ SEM } & \multirow{3}{*}{$P$-value } \\
\hline & \multirow[b]{2}{*}{ Control } & \multirow[b]{2}{*}{ Low } & \multirow[b]{2}{*}{ Medium } & \multirow[b]{2}{*}{ High } & & \\
\hline & & & & & & \\
\hline Empty body weight, kg & $325.2^{\mathrm{b}}$ & $350.3^{\mathrm{b}}$ & $393.6^{\mathrm{a}}$ & $418.9^{\mathrm{a}}$ & 13.44 & $<0.001$ \\
\hline Hot carcass weight, kg & $202.1^{\mathrm{b}}$ & $225.3^{\mathrm{b}}$ & $253.1^{\mathrm{a}}$ & $267.4^{\mathrm{a}}$ & 9.74 & 0.001 \\
\hline Cold carcass weight, $\mathrm{kg}$ & $196.9^{b}$ & $219.6^{\mathrm{b}}$ & $247.0^{\mathrm{a}}$ & $261.2^{\mathrm{a}}$ & 9.43 & $<0.001$ \\
\hline Hot carcass yield, $\%$ & $0.539^{b}$ & $0.574^{\mathrm{a}}$ & $0.577^{\mathrm{a}}$ & $0.574^{\mathrm{a}}$ & 0.72 & 0.005 \\
\hline Cold carcass yield, $\%$ & $0.525^{\mathrm{b}}$ & $0.560^{\mathrm{a}}$ & $0.563^{\mathrm{a}}$ & $0.560^{\mathrm{a}}$ & 0.70 & 0.004 \\
\hline Carcass bone, $\%$ & $18.3^{\mathrm{b}}$ & $17.4^{\mathrm{ab}}$ & $16.7^{\mathrm{a}}$ & $17.1^{\mathrm{a}}$ & 0.41 & 0.099 \\
\hline Carcass muscle, $\%$ & 70.1 & 71.1 & 69.9 & 69.2 & 0.62 & 0.228 \\
\hline Carcass fat,$\%$ & 11.2 & 11.0 & 12.4 & 13.3 & 0.68 & 0.105 \\
\hline Body length, cm & $122^{\mathrm{b}}$ & $121.6^{\mathrm{b}}$ & $127^{\mathrm{ab}}$ & $132^{\mathrm{a}}$ & 2.56 & 0.035 \\
\hline LM area, $\mathrm{cm}^{2}$ & $58.1^{\mathrm{b}}$ & $63.2^{\mathrm{ab}}$ & $67.2^{\mathrm{a}}$ & $70.6^{\mathrm{a}}$ & 3.32 & 0.086 \\
\hline $\mathrm{LM}$ area, $\mathrm{cm}^{2}, \mathrm{~kg}^{-1}$ & 0.294 & 0.289 & 0.270 & 0.270 & 0.01 & 0.403 \\
\hline
\end{tabular}

$\mathrm{n}=28$.

abc - Values within a row with different superscripts differ significantly at $P<0.10$. 


\section{Discussion}

The high forage availability in all seasons did not seem to have limited the voluntary intake, but the nutritional quality of the pasture was affected by the seasons (Table 2). During the dry season, frequently there was a drastic decrease in the nutritional quality of grasses, as indicated mainly by the decreased CP content and the increased concentration of lignin in the cell wall (DETMANN et al., 2014; DETMANN et al., 2015). In this season, forages often present a CP content below $70 \mathrm{~g} \mathrm{~kg}^{-1} \mathrm{DM}$ (DE PAULA et al., 2011; LAZZARINI et al., 2009; SAMPAIO et al., 2010). Therefore, the CP content ( $79 \mathrm{~g} \mathrm{~kg}^{-1}$ DM; Table 2) during the dry season observed in the current study can be considered atypical and may be attributed to higher rainfall, which is not commonly observed in this season.

The nutritional quality of the pasture was better in the other seasons than during the dry season; in particular, the CP content was $111 \mathrm{~g} \mathrm{~kg}^{-1} \mathrm{DM}$ in the rainy season. However, regardless of the season, tropical grasses alone rarely provide a balanced diet for grazing cattle because they have nutritional constraints that limit pasture intake and digestibility (DETMANN et al., 2014; DETMANN et al., 2015). There is an unbalanced protein:energy ration in tropical pastures with a relative excess of energy. This type of unbalance decreases the efficiency of the utilization of metabolizable energy and limits intake due to heat production from energy excess (DETMANN et al., 2014).

During the rainy-dry transition season (suckling phase), the good nutritional quality of the pasture (CP, 10.1\%) and the contribution of milk as main feed seem to prevent variations in DMI (average of $24.7 \mathrm{~g} \mathrm{~kg}^{-1} \mathrm{BW}$ ). Lopes et al. (2014) reported that calves receiving supplementation with different levels of $\mathrm{CP}$ in tropical pastures $(\mathrm{CP}, 11.6 \%)$ had similar DMI (19.8 $\left.\mathrm{g} \mathrm{kg}^{-1} \mathrm{BW}\right)$. In contrast, Valente et al. (2014) carried out a study under similar conditions and verified that the intake of high protein supplements increased the DMI (14.68 $\mathrm{g} \mathrm{kg}^{-1}$
BW for control versus $17.9 \mathrm{~g} \mathrm{~kg}^{-1} \mathrm{BW}$ on average for supplemented animals). However, the forage in those studies presented a CP content of $8.8 \%$, which was lower than that observed in the current study and in Lopes et al. (2014). This difference in forage composition may explain the differences in results between these studies. The NRC (1996) recommended a DMI of $35.3 \mathrm{~g} \mathrm{~kg}^{-1} \mathrm{BW}$ for animals of $150 \mathrm{~kg}$ initial BW and $450 \mathrm{~kg}$ maturity BW, with an ADG of $0.75 \mathrm{~kg}$.

On the other hand, during the dry season, when cattle are often graze low-quality forage, positive effects of protein supplementation on voluntary intake and digestibility are observed until diet presents a CP content of $80-100 \mathrm{~g} \mathrm{~kg}^{-1} \mathrm{DM}$ (DETMANN et al., 2014; SAMPAIO et al., 2010; SOUZA et al. 2010). This benefit generally occurs because of a more adequate protein status and consequently increases the forage intake. There is, therefore, a relationship between FDMI and dietary $\mathrm{CP}$, which reinforces the idea that an increase in dietary $\mathrm{CP}$ content positively affects intake when the diet is deficient in nitrogen. At the same time, harmful responses to intake could result if an excessive CP is provided by supplementation (DETMANN et al., 2014). These authors recommended a minimum $\mathrm{CP}$ content of $80 \mathrm{~g} \mathrm{~kg}^{-1} \mathrm{DM}$ to ensure that ruminal microbial growth is not compromised and thus encourage efficient utilization of the fiber in basal forage. In the present study, the observed decrease in FDMI can probably be attributed to better forage quality, even during the dry season, and the higher levels of supplementation provided compared with other studies. Note, however, that the deleterious effect on FDMI was more pronounced in the dry season.

Valente et al. (2014) reported that supplemented and non-supplemented young bulls had similar FDMI in the dry season (pasture with 5.5\% CP), but all supplemented young bulls had greater DMI than non-supplemented ones. These results provide evidence that DMI and FDMI are strongly affected by the forage composition, especially by CP content, 
that modifies throughout the year (Table 2), and by supplementation levels (Ex: high supplementation decrease forage intake; Table 3). Despite CP content in forage, responses to supplemental protein are also dependent on forage type as well as the cell wall structure of the forage (BOHNERT et al., 2011). These authors reported that the intake and digestibility of $\mathrm{C} 4$ forages increasing to a greater extent with supplementation compared with $\mathrm{C} 3$ forages of similar nutritional quality, and that the intake and digestibility of $\mathrm{C} 3$ forages appear to be greater than the intake and digestibility of $\mathrm{C} 4$ forages.

During the rainy season, although the available forage is not thought to be deficient in $\mathrm{CP}$, the utilization of forage is not considered to be optimal (DETMANN et al., 2014). According to Costa et al. (2011) and Detmann et al. (2015), there is an imbalance in the protein-to-energy ratio in tropical pastures with a relative excess of energy. The decrease in FDMI may occur to maintain the relationship between the metabolizable protein and energy at levels appropriate to animal comfort, preventing a relative excess of energy circulation. Thus, providing higher supplementation levels, such as through the medium and high supplementation plans in this study, increased the imbalance between the metabolizable protein and energy, resulting in a decrease in FDMI through metabolic mechanisms (COSTA et al., 2011; DETMANN et al., 2014). Furthermore, the authors suggest that providing supplements with high levels of protein, instead of higher levels (quantitative) of supplements with moderate protein content, can be more effective in maximizing FDMI. In fact, we noted an increase of $0.57 \mathrm{~g}$ in FDMI for each gram of supplement $\mathrm{kg}^{-1} \mathrm{BW}$ under low supplementation during the rainy season. Therefore, a moderate level of supplementation during this period may be more effective given the increase in FDMI.

The positive effects of protein supplementation or nitrogen compounds on FDMI are reflected in NDFI (LAZZARINI et al., 2013; SOUZA et al.,
2010). The addition of protein through increasing levels of supplementation also adds energy, which possibly has a deleterious effect on the intake of fiber. Moreover, the use of energy supplements has been found to promote deleterious effects (SOUZA et al., 2010). The lack of treatment effects on DMI, the lower concentration of NDF in the supplement in relation to the forage consumed, and the substitution effect presented above caused NDFI to decrease with increasing supplement intake compared with the control group in the rainy-dry and dry seasons.

The absence of differences in intake and the substitution effect of the pasture on the supplement as a result of a higher supplementation level also explain the higher CPI and TDN for animals that received supplements. In the suckling phase (creep feeding), the CPI for low and medium supplementation was very close to the values recommended by the NRC (1996), which was approximately $660 \mathrm{~g}$ for zebu of $150 \mathrm{~kg}$ with ADG of $0.750 \mathrm{~kg}$.

During the dry-rainy season, when the first rains occur, although the pasture is of better nutritional quality, we noted that CPD under all supplementation plans was lower compared with the other seasons. Although the protein levels increased rapidly in this stage with the emergence of new leaves, the chemical profile of CP during this period showed a high content of soluble protein and nitrogen compounds associated with insoluble fiber (DETMANN et al., 2015). Thus, there might have been a metabolic imbalance in the ratio of metabolizable protein to metabolizable energy, indicating the absence of readily fermentable carbohydrates, which resulted in the decreased use of the CP consumed. According to Valente et al. (2013), animals prefer to consume sprouts in detriment to mature part of plant, increasing the grazing time due to the increase in the time spent selecting. However, this grazing behavior was not observed in the current study, probably because of the minimal change in forage composition in relation to the dry season. 
In general, the improved energy and protein status of young bulls receiving greater supplementation supports the increased BW in each season. However, the rate of gain under different supplementation plans is strongly affected by the season and the change in body composition (Table 7). The response to protein supplementation over the course of the year is inversely proportional to the $\mathrm{CP}$ content in the pasture but is still positive regardless of the pasture quality (DETMANN et al., 2014). In addition, when the pasture presents a lower CP content, the improvement in performance is achieved by supplying the quantity deficit in $\mathrm{CP}$; however, when the pasture presents a high CP level, the performance may be improved by supplying the quality deficit (VALENTE et al., 2013).

The FBW for each phase reflects the rate of growth for each supplementation plan. In the rainydry season, the absence of significant differences can be attributed to the effective contribution of milk to the diet and the good forage quality, which maintained the DMI and nutritional status of nonsupplemented animals compared with calves that received supplementation by creep feeding. However, the additional BW gains over the seasons, despite being of smaller magnitude, and the greater nutrient intake resulted in greater weight at slaughter for animals that received supplementation during the entire production cycle. Valente et al. (2013) reported similar results. In the current research, the FBW (rainy season) showed increases of 1.9, 10.7, and $23.4 \%$ for animals under low, medium, and high supplementation, respectively, compared with nonsupplemented ones.

During the dry and dry-rainy seasons, the ADG of the animals was observed to be smaller compared with that in the rainy-dry season, which can be partially attributed to a reduction in the quality of forage. The highest ADG was observed for high supplementation, followed by that for medium supplementation. Even animals that received only mineral mixture showed gains that can be considered good for this period. This fact can have reduced the benefit of the supplementation.

During the finishing phase (rainy season), supplementation also resulted in greater weight gain, notably for animals under high and medium supplementation. There were additional gains of - 23, 72, and $126 \mathrm{~g} \mathrm{~d}^{-1}$ for low, medium, and high supplementation, respectively, compared with control. However, in this season, the efficiency of supplement use can be considered low, which can be attributed to the high forage quality and the differences in body composition of the animals, with the carcass fat tending to be greater for young bulls under high and medium supplementation. These animals started the finishing phase with greater FBW compared with non-supplemented young bulls.

Although the control animals showed positive weight gain even during the dry season, these gains were not sufficient to meet the growth rate of the animals in relation to carcass characteristics. Regarding EBW, $\mathrm{HCW}, \mathrm{CCW}, \mathrm{HCY}, \mathrm{CCY}, \mathrm{BL}$, and $\mathrm{AE}$, animals that were supplemented during all production phases were found to have higher yields than non-supplemented ones. In general, intermediate values were noted for low and medium supplementation, and the highest values were observed for high supplementation. This result reinforces the hypothesis on the need for supplementation at all stages of the production cycle for slaughter cattle in the end rainy season with aged 18 months in grazing systems.

\section{Conclusions}

Higher supplementation plans in the diet of beef cattle in tropical conditions increase the intake and digestibility of nutrients at different periods of the year and consequently improve the performance of the animals. However, there is a considerable substitution effect of forage by supplementation, notably for medium and high supplementation. 


\section{Acknowledgements}

The authors wish to thank the Fundação de Amparo à Pesquisa de Minas Gerais (FAPEMIG, Brazil) for financial support.

\section{References}

ALLEN, V. G.; BATELLO, C.; BERRETTA, E. J.; HODGSON, J.; KOTHMANN, M.; LI, X.; MCIVOR, J.; MILNE, J.; MORRIS, C.; PEETERS, A.; SANDERSON, M. An international terminology for grazing lands and grazing animals. Grass and Forage Science, Wiley, v. 66, n. 1, p. 2-28, 2011. DOI: $10.1111 /$ j.13652494.2010.00780.x

ASSOCIATION OF OFFICIAL ANALYTICAL CHEMISTS - AOAC. Official methods of analysis. 15 ed. Washington: AOAC International Method, 1990.

BOHNERT, D. W.; DELCURTO, T.; CLARK, A. A.; MERRILL, M. L.; FALCK, S. J.; HARMON, D. L. Protein supplementation of ruminants consuming low-quality cool- or warm-season forage: differences differences in intake and digestibility. Journal of Animal Science, Champaign, v. 89, n. 11, p. 3707-3717, 2011, DOI: $10.2527 /$ jas.2011-3915

COSTA, V. A. C.; DETMANN, E.; PAULINO, M. F.; VALADARES FILHO, S. C.; CARVALHO, I. P. C.; MONTEIRO, L. P. Intake and digestibility in cattle under grazing during rainy season supplemented with nitrogenous compounds and carbohydrates. Revista Brasileira de Zootecnia, Viçosa, v. 40, n. 8, p. 17881798, 2011. DOI: $10.1590 / \mathrm{S} 1516-35982011000800024$

DEL CURTO, T.; COCHRAN, R. C.; HARMON, D. L.; BEHARKA, A. A.; JACQUES, K. A.; TOWNE, G.; VANZANT, E. S. Supplementation of dormant tallgrassprairie forage: I. Influence of varying supplemental protein and(or) energy levels on forage utilization characteristics of beef steers in confinement. Journal of Animal Science, Champaign, v. 68, p. 515-531, 1990. DOI: $10.2527 / 1990.682515 x$

DE PAULA, N. F.; ZERVOUDAKIS, J. T.; CABRAL, L. S.; CARVALHO, D. M. G.; PAULINO, M. F.; HATAMOTO-ZERVOUDAKIS, L. K.; OLIVEIRA, A. A.; KOSCHECK, J. F. W. Infrequent supplementation and protein sources for growing steers grazing in the dry season: nutritional parameters. Revista Brasileira de Zootecnia, Viçosa, v. 40, n. 4, p. 882-891, 2011. DOI: 10.1590/S1516-35982011000400024

DETMANN, E.; PAULINO, M. F.; VALADARES
FILHO, S. C.; HUHTANEN, P. Nutritional aspects applied to grazing cattle in the tropics: a review based on Brazilian results. Semina: Ciências Agrárias, Londrina, v. 35 , n. 4 , p. $2829-2854$, 2015. Supplement. DOI: 10.5433/1679-0359.2014v35n4Suplp2829

DETMANN, E.; PAULINO, M. F.; ZERVOUDAKIS, J. T.; VALADARES FILHO, S. C.; EUCLIDES, R. F.; LANA, R. P.; QUEIRÓZ, D. S. Cromo e Indicadores internos na determinação do consumo de novilhos mestiços, suplementados, a pasto. Revista Brasileira de Zootecnia, Viçosa, v. 30, n. 5, p. 1600-1609, 2001. DOI: $10.1590 / \mathrm{S} 1516-35982001000600030$

DETMANN, E.; VALENTE, E. E. L.; BATISTA, E. D.; HUHTANEN, P. An evaluation of the performance and efficiency of nitrogen utilization in cattle fed tropical grass pastures with supplementation. Livestock Science, Amsterdam, v. 162, n. 4, p. 141-153, 2014. DOI: 10.1016/j.livsci.2014.01.029

DETMANN, E.; SOUZA, M. A.; VALADARES FILHO, S. C.; QUEIROZ, A. C.; BERCHIELLI, T. T.; SALIBA, E. O. S.; CABRAL, L. S.; PINA, D. S.; LADEIRA, M. M.; AZEVEDO, J. A. G. Métodos para análise de alimentos. 1.ed. Visconde do Rio Branco, Suprema.

FIGUEIRAS, J. F.; DETMANN, E.; PAULINO, M. F.; VALENTE, T. N. P.; VALADARES FILHO, S. C.; LAZZARINI, I. Intake and digestibility in cattle under grazing during dry season supplemented with nitrogenous compounds. Revista Brasileira de Zootecnia, Viçosa, v. 39 , n. 6 , p. $1303-1312$, 2010. DOI: $10.1590 /$ S151635982011000800024

LAZZARINI, I.; DETMANN, E.; PAULINO, M. F.; VALADARES FILHO, S. C.; VALADARES, R. F. D.; OLIVEIRA, F.A.; SILVA, P. T.; REIS, W. L. S. Nutritional performance of cattle grazing on low-quality tropical forage supplemented with nitrogenous compounds and/or starch. Revista Brasileira de Zootecnia, Viçosa, v. 42, n. 9, p. 664-674, 2013. DOI: 10.1590/S151635982013000900009

LAZZARINI, I.; DETMANN, E.; SAMPAIO, C. B.; PAULINO, M. F.; VALADARES FILHO, S. C.; SOUZA, M. A.; OLIVEIRA, F. A. Intake and digestibility in cattle fed low-quality tropical forage and supplemented with nitrogenous compounds. Revista Brasileira de Zootecnia, Viçosa, v. 38, n. 10, p. 2021-2030, 2009. DOI: 10.1590/ S1516-35982009001000024

LICITRA, G.; HERNANDEZ, T. M.; VAN SOEST, P. J. Standardization of procedures for nitrogen fractionation of ruminant feeds. Animal Feed Science and Technology, New York, v. 57, n. 4, p. 347-358, 1996. DOI: 10.1016/0377-8401(95)00837-3 
LOPES, S. A.; PAULINO, M. F.; DETMANN, E.; VALADARES FILHO, S. C.; VALENTE, E. E. L.; BARROS, L. V.; CARDENAS, J. E. G.; ALMEIDA, D. M.; MARTINS, L. S.; SILVA, A. G. Supplementation of suckling beef calves with different levels of crude protein on tropical pasture. Tropical Animal Health and Production, Amsterdam, v. 46, n. 2, p. 379-384, 2014. DOI: $10.1007 / \mathrm{s} 11250-013-0500-6$

MERTENS, D. R. Gravimetric determination of amylasetreated neutral detergent fiber in feeds with refluxing in beakers or crucibles: collaborative study. Journal AOAC International, Rockville, v. 85, n. 6, p. 1212-1240, 2002.

NATIONAL RESEARCH COUNCIL - NRC. Nutrient requirements of beef cattle. $7^{\text {th }}$ ed. Washington: National Academy Press, 1996. 242 p.

PATINO, H. O.; MEDEIROS, F. S.; PEREIRA, C. H.; SWANSON, K. C.; MCMANUS, C. Productive performance, meat quality and fatty acid profile of steers finished in confinement or supplemented at pasture. Animal, Champanelle, v. 9, n. 6, p. 966-972, 2015. DOI: $: 10.1017 / \mathrm{S} 1751731115000105$

SAMPAIO, C. B.; DETMANN, E.; PAULINO, M. F.; VALADARES FILHO, S. C.; SOUZA, M. A.; LAZZARINI, I.; PAULINO, P. V. R.; QUEIROZ, A. C. Intake and digestibility in cattle fed low-quality tropical forage and supplemented with nitrogenous compounds. Tropical Animal Health and Production, Amsterdam, v. 42, n. 7, p. 1471-1479, 2010. DOI: 10.1007/s11250-0109581-7

STATISTICAL ANALYSIS SYSTEM INSTITUTE SAS. The SAS System, release 9.3. SAS Institute Inc., Cary: NC, 2016.
SOUZA, M. A.; DETMANN, E.; PAULINO, M. F.; SAMPAIO, C. B.; LAZZARINI, I.; VALADARES FILHO, S. C. Intake, digestibility, and rumen dynamics of neutral detergent fibre in cattle fed low-quality tropical forage and supplemented with nitrogen and/or starch. Tropical Animal Health and Production, Amsterdam, v. 42, n. 6, p. 1299-1310, 2010. DOI: $10.1007 / \mathrm{s} 11250-010-$ 9566-6

TITGEMEYER, E. C.; ARMENDARIZ, C. K.; BINDEL, D. J.; GREENWOOD, R. H.; LOEST, C. A. Evaluation of titanium dioxide as a digestibility marker for cattle. Journal of Animal Science, Champaign, v. 79, n. 4, p. 1059-1063, 2001. DOI: 10.2527/2001.7941059x

VALENTE, E. E. L.; PAULINO, M. F.; BARROS, L. V.; ALMEIDA, D. M.; MARTINS, L. S.; CABRAL, C. H. A. Nutritional evaluation of young Bulls on tropical pasture receiving supplements with different protein:carbohydrate ratios. Asian Australasian Journal Animal Science, Bethesda, v. 27, n. 10, p. 1452-1460, 2014. DOI: 10.5713 /ajas.2014.14085

VALENTE, E. E. L.; PAULINO, M. F.; DETMANN, E.; VALADARES FILHO, S. C.; LOPES, S. A. Performance of young bulls supplemented with different relation of protein and carbohydrate from suckling phase until slaughter in tropical pasture. Journal of Animal and Plant Science, Lahore, v. 18, n. 2, p. 2711-2722, 2013. DOI: 10.5713/ajas.2014.14085

VALENTE, T. N. P.; DETMANN, E.; QUEIROZ, A. C.; VALADARES FILHO, S. C.; GOMES, D. I.; FIGUEIRAS, J. F. Evaluation of ruminal degradation profiles of forages using bags made from different textiles. Revista Brasileira de Zootecnia, Viçosa, v. 40, n. 11 , p. $2565-2573,2011$. DOI: $10.1590 / \mathrm{S} 1516-$ 35982011001100039 